\title{
$n-6: n-3$ PUFA ratio is involved in regulating lipid metabolism and inflammation in pigs
}

\author{
Yehui Duan ${ }^{1,2}$, Fengna $\mathrm{Li}^{1 *}$, Lili Li ${ }^{1}$, Juexin $\mathrm{Fan}^{3}$, Xiaoming Sun ${ }^{1,4}$ and Yulong Yin ${ }^{1 *}$ \\ ${ }^{1}$ Key Laboratory of Agro-ecological Processes in Subtropical Region, Hunan Provincial Engineering Research \\ Center of Healthy Livestock, Institute of Subtropical Agriculture, Chinese Academy of Sciences, Scientific Observing \\ and Experimental Station of Animal Nutrition and Feed Science in South-Central, Ministry of Agriculture, \\ No. 644 Yuanda Road, Furong District, Changsha Hunan 410125, People's Republic of China \\ ${ }^{2}$ Institute of Bast Fiber Crops, Chinese Academy of Agricultural Sciences, Changsha Hunan 410005, \\ People's Republic of China \\ ${ }^{3}$ College of Animal Sciences, Hunan Agricultural University, Changsha Hunan 410128, People's Republic of China \\ ${ }^{4}$ The Graduate School of the Chinese Academy of Sciences, Beijing 100039, People's Republic of China \\ (Submitted 11 April 2013 - Final revision received 12 June 2013 - Accepted 10 July 2013 - First published online 15 August 2013)
}

\section{Abstract}

The objective of the present study was to investigate the optimal dietary $n-6: n-3$ PUFA ratios that regulate lipid metabolism and inflammation in pigs. A total of ninety-six cross-bred (Large White $\times$ Landrace) growing-finishing pigs (73.8 (sEm 1.6) $\mathrm{kg}$ ) were chosen and fed one of the four isoenergetic diets with $n-6: n-3$ PUFA ratios of 1:1, 2·5:1, 5:1 and 10:1. The growth performance of pigs fed the diet with an $n$-6:n-3 PUFA ratio of 5:1 was the best, but the group fed the diet with an $n-6: n-3$ PUFA ratio of 1:1 had the highest muscle mass and the lowest adipose tissue mass $(P<0 \cdot 05)$. The concentrations of IL- 6 and IL-1 $\beta$ of pigs fed the diet with an $n-6: n-3$ PUFA ratio of $1: 1$ were decreased compared with those of the other groups $(P<0 \cdot 05)$. The concentration of adiponectin of pigs fed the diet with an $n-6: n-3$ PUFA ratio of $1: 1$ was also markedly decreased, but the concentration of leptin was increased compared with that of the groups fed the diets with $n-6: n-3$ PUFA ratios of 5:1 and 10:1 ( $P<0 \cdot 05)$. Additionally, the optimal dietary ratios of $n-6: n-3$ PUFA of 1:1 and 5:1 markedly suppressed the expression levels of lipid metabolism-related genes and proteins such as phosphoinositide-3-kinase- $\alpha$, fatty acid transport protein- 1 and PPAR $\gamma$. They also significantly suppressed the expression levels of the inflammatory cytokines IL- $1 \beta$, TNF- $\alpha$ and IL- 6 . The results indicated that the optimal $n-6: n-3$ PUFA ratios of 1:1 and 5:1 exerted beneficial effects on lipid metabolism and inflammatory system, leading to the availability of more energy and nutrients for high performance and homeostatic pathways.

\section{Key words: $\boldsymbol{n}-\mathbf{6}: \boldsymbol{n}-3$ ratios: PUFA: Lipid metabolism: Inflammation: Pigs}

Essential fatty acids, including $n-6$ and n-3 PUFA, cannot convert into each other in the body. Hence, PUFA are crucial components of the food or diet ${ }^{(1,2)}$. It has been widely accepted that the present Western diet is low in $n-3$ fatty acids with a ratio of $n-6: n-3$ ranging from $15: 1$ to $20: 1$, instead of $1: 1$, while a value as much as possibly close to $1: 1$ is considered protective against degenerative pathologies ${ }^{(3,4)}$. Both $n-6$ and $n-3$ PUFA can regulate gene expression: $n-3$ PUFA exert suppressive effects on chronic diseases; conversely, $n-6$ PUFA increase the concentrations of inflammatory mediators $^{(2,5)}$. On the one hand, it has been hypothesised that diets with high ratios of $n-6: n-3$ PUFA may increase the production of inflammatory mediators and lead to the pathology of the metabolic syndrome, such as cognitive impairment, Alzheimer's disease and type 2 diabetes $^{(6-10)}$. On the other hand, diets with higher ratios of $n-6: n-3$ fatty acids may lead to the pathology of the metabolic syndrome ${ }^{(5)}$. Therefore, lowering the $n-6: n-3$ PUFA ratio in diets is beneficial for the health of animals and humans.

A lower $n-6: n-3$ PUFA ratio is required for the prevention and management of chronic diseases ${ }^{(2)}$. Some previous studies have suggested that an $n-6: n-3$ PUFA ratio of 5:1 suppresses inflammation in patients with asthma ${ }^{(3)}$. It should be noted that the biological effects of $n-6$ and $n-3$ PUFA are not always in opposition. It is widely accepted that the $n$-6-derived lipoxins also exert anti-inflammatory effects ${ }^{(3)}$. Due to their opposing and coordinative effects, a proper balance between $n-6$ and $n-3$ fatty acids in the diet is very important to maintain the optimum growth and development of animals and also the health of humans ${ }^{(11)}$.

Abbreviations: FATP-1, fatty acid transport protein-1; PI3K $\alpha$, phosphoinositide-3-kinase- $\alpha$.

*Corresponding authors: F. Li, fax +86 7318461 2685, email lifengna@isa.ac.cn; Y. Yin, email yinyulong@isa.ac.cn 
The morphology and physiology of the organs of humans and pigs are similar. Thus, the pig is an excellent animal model for studying human nutrition and metabolism. In the present study, we used a pig model to investigate the optimal dietary ratios of $n-6: n-3$ PUFA that regulate lipid metabolism and inflammation.

\section{Materials and methods}

\section{Animals and diets}

All procedures followed in the present experiment were approved by the committee on animal care of the Institute of Subtropical Agriculture, the Chinese Academy of Sciences.

A total of ninety-six male cross-bred (Large White $\times$ Landrace) pigs with a similar initial weight $(73.8$ (SEM 1.6) kg) were chosen and divided into four groups using a randomised complete block design based on body weight, with six replicates (pens) per group and four pigs per replicate. The pigs in the four groups were fed isoenergetic diets (3\% fat) with different $n-6: n-3$ ratios, prepared using 3.00, 1.50, 0.75 and $0.30 \%$ of linseed oil to replace equivalent amounts of soyabean oil to make the dietary $n-6: n-3$ ratios of the four diets about $1: 1,2 \cdot 5: 1,5: 1$ and 10:1, respectively. The composition and nutrient levels of the four diets are listed in Table 1. All the pigs had ad libitum access to diets and water and consumed the diets for 2 months.

\section{Sample collection}

Body weights and feed intake of the pigs were recorded after an overnight fast to calculate weight gain and feed conversion.

Table 1. Composition and nutrient levels of the diets (air-dry basis, \%)

\begin{tabular}{|c|c|c|c|c|}
\hline \multirow[b]{2}{*}{ Ingredients (\%) } & \multicolumn{4}{|c|}{$n-6: n-3$} \\
\hline & $1: 1$ & $2 \cdot 5: 1$ & $5: 1$ & $10: 1$ \\
\hline Maize & 65.50 & $65 \cdot 50$ & 65.50 & $65 \cdot 50$ \\
\hline Soyabean meal & 22.50 & 22.50 & $22 \cdot 50$ & 22.50 \\
\hline Wheat bran & $6 \cdot 60$ & 6.60 & 6.60 & $6 \cdot 60$ \\
\hline Soyabean oil & 0 & 1.50 & $2 \cdot 25$ & $2 \cdot 70$ \\
\hline Linseed oil & 3.00 & 1.50 & 0.75 & 0.30 \\
\hline Dicalcium phosphate & 0.50 & 0.50 & 0.50 & 0.50 \\
\hline Limestone & 0.60 & 0.60 & 0.60 & 0.60 \\
\hline Salt & 0.30 & 0.30 & 0.30 & 0.30 \\
\hline Premix $†$ & 1.00 & 1.00 & 1.00 & 1.00 \\
\hline \multicolumn{5}{|l|}{ Nutrient level (\%) } \\
\hline Digestible energy (MJ/kg) & 14.20 & $14 \cdot 20$ & $14 \cdot 20$ & $14 \cdot 20$ \\
\hline Crude protein & $15 \cdot 50$ & $15 \cdot 50$ & $15 \cdot 50$ & $15 \cdot 50$ \\
\hline SID Lys & 0.69 & 0.69 & 0.69 & 0.69 \\
\hline SID Met & 0.23 & 0.23 & 0.23 & 0.23 \\
\hline $\mathrm{Ca}$ & 0.52 & 0.52 & 0.52 & 0.52 \\
\hline Available $\mathrm{P}$ & 0.19 & 0.19 & $0 \cdot 19$ & 0.19 \\
\hline
\end{tabular}

SID, standardised ileal digestible.

* To replace equivalent amounts of soyabean oil, $3.00,1.50,0.75$ and $0.30 \%$ of linseed oil were used, making the dietary $n-6: n-3$ ratios about $1: 1,2 \cdot 5: 1,5: 1$ and 10:1, respectively (see Table 2).

†Premix provided per kg diet: retinol acetate, $13500 \mathrm{IU}$; cholecalciferol, $3600 \mathrm{IU}$; $\mathrm{DL}-\alpha$-tocopherol acetate, $15 \mathrm{IU}$; thiamin, $3.0 \mathrm{mg}$; riboflavin, $7.8 \mathrm{mg}$; cobalamin, $0.024 \mathrm{mg}$; pyridoxine, $3.0 \mathrm{mg}$; menadione, $3.0 \mathrm{mg}$; pantothenic acid, $150 \mathrm{mg}$; niacin, $30 \mathrm{mg}$; choline, $600 \mathrm{mg}$; folic acid, $1.5 \mathrm{mg}$; biotin, $0.045 \mathrm{mg} ; \mathrm{Cu}$ (as $\mathrm{CuSO}_{4} \cdot 5 \mathrm{H}_{2} \mathrm{O}$ ), $10 \mathrm{mg}$; $\mathrm{Fe}$ (as $\mathrm{FeSO}_{4} \cdot 7 \mathrm{H}_{2} \mathrm{O}$ ), $80 \mathrm{mg} ; \mathrm{Zn}$ (as $\mathrm{ZnSO}_{4} \cdot 7 \mathrm{H}_{2} \mathrm{O}$ ), $80 \mathrm{mg}$; $\mathrm{Mn}$ (as $\mathrm{MnSO}_{4} \cdot \mathrm{H}_{2} \mathrm{O}$ ), $10 \mathrm{mg}$; Se (as $\mathrm{Na}_{2} \mathrm{SeO}_{3}$ ), $0.30 \mathrm{mg}$; I (as KI), $0.30 \mathrm{mg}$.
From each replicate, one pig was chosen and killed at the end of the feeding test. Blood samples were collected via jugular vein puncture into $10 \mathrm{ml}$ tubes, and serum was separated by centrifugation at $2000 \mathrm{~g}$ for $15 \mathrm{~min}$ at $4^{\circ} \mathrm{C}$ and then stored at $-20^{\circ} \mathrm{C}$ until analysis. The pigs were electrically stunned, exsanguinated and eviscerated. Immediately, samples (about $5 \mathrm{~g}$ ) of the longissimus lumborum muscle and subcutaneous adipose tissue dissected from the left side of the carcasses were placed in liquid $\mathrm{N}_{2}$ and then stored at $-80^{\circ} \mathrm{C}$ until further analyses. Later, skeletal muscle and fat were dissected from the right side of the carcasses and weighed separately. The weights were used to calculate the total percentages of these components in the carcasses.

\section{Measurement of the concentrations of secreted adipokines by ELISA}

The serum concentrations of IL-6 (R\&D), TNF- $\alpha$ (Endogen), IL-1 $\beta$, leptin, total adiponectin (Uscn) and insulin (Mercodia) were quantified using ELISA kits for porcine assay according to the manufacturers' instructions. All the samples were measured in six replicates.

\section{Real-time PCR}

Total RNA was extracted from the harvested tissue using the TRIzol reagent (Invitrogen). Primers for the selected genes (Table 2) were designed using the Oligo 6.0 software. RT was performed using the AMV Reverse Transcriptase Kit (Promega). The relative expression levels of the target genes were determined using quantitative real-time PCR, performed with an ABI 7900 PCR system (ABI Biotechnology). The final volume of the reaction mixtures $(20 \mu \mathrm{l})$ contained diluted complementary DNA and SYBR Green I (Molecular Probes) as a PCR core reagent. $\beta$-Actin was used as a housekeeping gene or an internal control to normalise the expression of target genes.

The relative quantification of gene amplification by RT-PCR was performed using the value of the threshold cycle $\left(C_{t}\right)$. The comparative $C_{\mathrm{t}}$ value method using the formula $2^{-\Delta \Delta C_{\mathrm{t}}}$ was employed to quantify the expression levels of phosphoinositide-3-kinase- $\alpha(P I 3 K \alpha)$, fatty acid transport protein-1 (FATP-1), PPAR $\gamma, I L-1 \beta, T N F-\alpha$ and $I L-6$ relative to those of $\beta$-actin using the following formula:

$$
\begin{aligned}
2^{-\Delta \Delta C_{\mathrm{t}}}\left(\Delta \Delta C_{\mathrm{t}}=\right. & \left.C_{\text {tgene of interest }}-C_{\mathrm{t}} \beta \text {-actin }\right)_{\text {treat }} \\
& -\left(C_{\mathrm{t}} \text { gene of interest }-C_{\mathrm{t}} \beta \text {-actin }\right)_{\text {untreat }} .
\end{aligned}
$$

\section{Western blotting}

Tissue samples (about 500-800 mg) were powdered in liquid $\mathrm{N}_{2}$ to extract total protein. Approximately $30 \mu \mathrm{g}$ of the protein sample were size-fractionated on SDS-PAGE gel and transferred onto polyvinylidene difluoride membranes (Millipore) under the conditions of $30 \mathrm{~mA}$ and $4^{\circ} \mathrm{C}$ overnight. Later, the membranes were blocked with $5 \%$ bovine serum albumin (BSA) for $1 \mathrm{~h}$ and then probed overnight at $4^{\circ} \mathrm{C}$ with the antibodies against FATP-1 (ab69458; Abcam) at 1:800 dilution and 
Table 2. Primers used for real-time PCR

\begin{tabular}{|c|c|c|c|c|}
\hline Genes & Primers & Sequences $\left(5^{\prime}-3^{\prime}\right)$ & $\begin{array}{l}\text { Size } \\
\text { (bp) }\end{array}$ & $\begin{array}{c}T_{\mathrm{A}} \\
\left({ }^{\circ} \mathrm{C}\right)\end{array}$ \\
\hline$P / 3 K \alpha$ & $\begin{array}{l}\text { Forward } \\
\text { Reverse }\end{array}$ & $\begin{array}{l}\text { CTGGACTGCCTGCGCTACTG } \\
\text { TGGTGGTGCTGCGGTGAAT }\end{array}$ & 334 & 60 \\
\hline FATP-1 & $\begin{array}{l}\text { Forward } \\
\text { Reverse }\end{array}$ & $\begin{array}{l}\text { GGAGTAGAGGGCAAAGCAGG } \\
\text { AGGTCTGGCGTGGGTCAAAG }\end{array}$ & 208 & 64 \\
\hline PPAR & $\begin{array}{l}\text { Forward } \\
\text { Reverse }\end{array}$ & $\begin{array}{l}\text { TGACCATGGTTGACACCG } \\
\text { AAGCATGAACTCCATAGTGG }\end{array}$ & 381 & 58 \\
\hline$I L-1 \beta$ & $\begin{array}{l}\text { Forward } \\
\text { Reverse }\end{array}$ & $\begin{array}{l}\text { GCTAACTACGGTGACAACAA } \\
\text { TCTTCATCGGCTTCTCCACT }\end{array}$ & 196 & 64 \\
\hline$T N F-\alpha$ & $\begin{array}{l}\text { Forward } \\
\text { Reverse }\end{array}$ & $\begin{array}{l}\text { CCACGTTGTAGCCAATGTCA } \\
\text { CAGCAAAGTCCAGATAGTCG }\end{array}$ & 395 & 64 \\
\hline IL-6 & $\begin{array}{l}\text { Forward } \\
\text { Reverse }\end{array}$ & $\begin{array}{l}\text { TCAGTCCAGTCGCCTTCTCC } \\
\text { GGCATTTGTGGTGGGGTTAG }\end{array}$ & 494 & 64 \\
\hline$\beta$-Actin & $\begin{array}{l}\text { Forward } \\
\text { Reverse }\end{array}$ & $\begin{array}{l}\text { TGCGGGACATCAAGGAGAAG } \\
\text { AGTTGAAGGTGGTCTCGTGG }\end{array}$ & 216 & 64 \\
\hline
\end{tabular}

$\overline{T_{\mathrm{A}} \text {, annealing temperature; } \mathrm{PI} 3 \mathrm{~K} \alpha \text {, phosphoinositide-3-kinase- } \alpha \text {; FATP-1, fatty acid }}$ transport protein-1.

PPARy (\#2435; Cell Signaling Technology) and PI3K $\alpha$ (\#4255; Cell Signaling Technology) at 1:1000 dilution. The membranes were then rinsed with Tris-buffered saline plus $0 \cdot 1 \%$ Tween 20 three times and incubated with peroxidase-conjugated goat anti-rabbit or anti-mouse $\operatorname{IgG}$ for $1 \mathrm{~h}$ at $1: 5000$ dilution at room temperature; $\beta$-actin monoclonal antibody (sc47778) at 1:2000 dilution was used to normalise the amount of proteins (Santa Cruz Biotechnology). The protein bands were visualised using a chemiluminescent reagent. The density of the protein bands was determined using the Alpha Imager 2200 software (Alpha Innotech Corporation).

\section{Statistical analyses}

All the results are expressed as means with their standard errors. Statistical analyses were carried out using one-way ANOVA, SAS 8.2 (SAS Institute, Inc.), followed by a Tukey test of multiple comparisons. In case of a $P$ value $<0.05$, differences were considered to be statistically significant.

\section{Results}

Effects of dietary n-6:n-3 PUFA ratios on the growth performance and body composition of pigs

The fatty acid contents of the experimental diets are listed in Table 3. The measured values coincided better with the

Table 3. Fatty acid composition of the diets

\begin{tabular}{lcrrr}
\hline & \multicolumn{4}{c}{$n-6: n-3$} \\
\cline { 2 - 5 } Items & $1: 1$ & $2 \cdot 5: 1$ & $5: 1$ & $10: 1$ \\
\hline $16: 0$ & $8 \cdot 46$ & $9 \cdot 61$ & $10 \cdot 84$ & $11 \cdot 19$ \\
$16: 1$ & $0 \cdot 07$ & $0 \cdot 07$ & $0 \cdot 07$ & $0 \cdot 08$ \\
$18: 0$ & $2 \cdot 46$ & $2 \cdot 62$ & $2 \cdot 82$ & $2 \cdot 95$ \\
$18: 1$ & $24 \cdot 25$ & $25 \cdot 26$ & $25 \cdot 54$ & $26 \cdot 18$ \\
$18: 2 n-6$ & $34 \cdot 40$ & $44 \cdot 98$ & $50 \cdot 40$ & $54 \cdot 29$ \\
$18: 3 n-3$ & $30 \cdot 31$ & $17 \cdot 42$ & $10 \cdot 29$ & $5 \cdot 27$ \\
$22: 6 n-3$ & $0 \cdot 05$ & $0 \cdot 04$ & $0 \cdot 04$ & $0 \cdot 04$ \\
$\sum n-6: \sum n-3^{*}$ & $1 \cdot 1: 1$ & $2 \cdot 6: 1$ & $4 \cdot 9: 1$ & $10 \cdot 2: 1$ \\
\hline${ }^{*} n-6: n-3=(18: 2) /(18: 3+22: 6)$. & & &
\end{tabular}

${ }^{*} n-6: n-3=(18: 2) /(18: 3+22: 6)$. calculated values. The growth performance and body composition of pigs fed diets with different $n-6: n-3$ PUFA ratios are summarised in Table 4. Compared with those of the other groups, the body weight and daily weight gain of pigs fed the diet with an $n-6: n-3$ PUFA ratio of 5:1 were increased significantly $(P<0.05)$, while the daily intake and feed conversion rate of this group were decreased $(P<0.05)$. However, the group fed the diet with an $n-6: n-3$ PUFA ratio of $1: 1$ had high muscle mass and low adipose tissue mass. We speculated that an optimal $n-6: n-3$ PUFA ratio could regulate the crosstalk between the muscle and adipose tissue of pigs.

\section{Effects of different n-6:n-3 PUFA ratios on serum glucose and cytokine concentrations}

As shown in Table 5, the concentrations of glucose, TNF- $\alpha$ and insulin were not different among the treatment groups. The concentrations of IL- 6 and IL- $1 \beta$ of pigs fed the diet with an $n$-6:n-3 PUFA ratio of $1: 1$ were decreased by $12 \cdot 3$ and $37.9 \%(P<0.05)$, respectively, compared with those fed diets with an $n-6: n-3$ PUFA ratio of 10:1. Furthermore, the serum concentrations of adiponectin of pigs fed the diet with an $n$-6:n-3 PUFA ratio of $1: 1$ were also decreased by $13.5 \%$ compared with those of pigs fed the diet with an $n$-6:n-3 PUFA ratio of 10:1 ( $P<0 \cdot 05)$; on the contrary, the concentration of leptin of this group was increased by $16.4 \%(P<0.05)$.

\section{Effects of dietary n-6:n-3 PUFA ratios on the gene expression levels of pigs}

The expression levels of genes in the muscle and adipose tissue of pigs are shown in Fig. 1(A) and (B). The expression levels of $P I 3 K \alpha$ mRNA were lower $(P<0.05)$ in the groups fed diets with $n$-6:n-3 PUFA ratios of $1: 1$ and 2.5:1, and there was no difference between these two groups $(P>0.05)$. The expression levels of the FATP-1 gene in the muscle and adipose tissue of pigs fed diets with an $n-6: n-3$ PUFA ratio of $1: 1$ were the lowest $(P<0.05)$, and those fed diets with $n-6: n-3$ PUFA ratios of $1: 1$ and $2 \cdot 5: 1$ exhibited down-regulated expression levels of the PPAR $\gamma$ gene in the muscle and adipose tissue $(P<0.05)$; also, there was no difference $(P<0.05)$ between these two groups. Interestingly, the diet with an $n-6: n-3$ PUFA ratio of 1:1 markedly down-regulated the expression levels of $I L-1 \beta$, $T N F-\alpha$ and $I L-6$ genes in the skeletal muscle and adipose tissue of pigs $(P<0.05)$.

\section{Effect of dietary n-6:n-3 PUFA ratios on the protein expression levels of pigs}

The relative expression levels of PI3K $\alpha$, FATP-1 and PPAR $\gamma$ proteins are shown in Fig. 2(A) and (B). The expression level of the $\mathrm{PI} 3 \mathrm{~K} \alpha$ protein was higher in the muscle of pigs fed the diet with an $n$-6:n-3 PUFA ratio of 10:1 $(P<0 \cdot 05)$. The trend of the expression levels of the FATP-1 protein was the same as those of the gene in the muscle. However, the trend of the expression levels of the FATP-1 protein in the adipose tissue was the reverse. The diets with $n-6: n-3$ PUFA 
Table 4. Effect of dietary $n-6: n-3$ PUFA ratios on the growth performance of pigs

\begin{tabular}{|c|c|c|c|c|c|c|}
\hline \multirow[b]{2}{*}{ Items } & \multicolumn{5}{|c|}{$n-6: n-3$} & \multirow[b]{2}{*}{$P$} \\
\hline & $1: 1$ & $2 \cdot 5: 1$ & $5: 1$ & $10: 1$ & SEM & \\
\hline Initial body weight (kg) & 74.58 & $72 \cdot 75$ & 73.92 & 73.83 & 0.64 & 0.27 \\
\hline Final body weight (kg) & $125 \cdot 58^{\mathrm{b}}$ & $125 \cdot 77^{\mathrm{b}}$ & $129 \cdot 75^{a}$ & $126 \cdot 03^{\mathrm{b}}$ & 0.98 & 0.04 \\
\hline Daily weight gain $(\mathrm{kg} / \mathrm{d})$ & $0.85^{\mathrm{b}}$ & $0.88^{\mathrm{b}}$ & $0.93^{\mathrm{a}}$ & $0.87^{\mathrm{b}}$ & 0.01 & 0.02 \\
\hline Feed intake $(\mathrm{kg} / \mathrm{d})$ & $2 \cdot 70^{\mathrm{a}}$ & $2 \cdot 78^{\mathrm{a}}$ & $2 \cdot 56^{\mathrm{b}}$ & $2 \cdot 77^{\mathrm{a}}$ & 0.03 & $<0.01$ \\
\hline Feed conversion rate (gain:feed) & $3 \cdot 17^{\mathrm{a}}$ & $3 \cdot 15^{\mathrm{a}}$ & $2 \cdot 75^{\mathrm{b}}$ & $3 \cdot 18^{\mathrm{a}}$ & 0.06 & $<0.01$ \\
\hline Muscle mass $(\%)^{\star}$ & $34 \cdot 30^{\mathrm{a}}$ & $32 \cdot 00^{\mathrm{b}}$ & $31 \cdot 38^{\mathrm{b}}$ & $31 \cdot 25^{\mathrm{b}}$ & 0.58 & 0.02 \\
\hline Adipose tissue mass $(\%)^{*}$ & $8 \cdot 21^{\mathrm{b}}$ & $9 \cdot 02^{b}$ & $10 \cdot 51^{\mathrm{a}, \mathrm{b}}$ & $12.99^{\mathrm{a}}$ & 1.03 & 0.04 \\
\hline
\end{tabular}

${ }^{a, b}$ Values with unlike letters within a row were significantly different $(P<0.05)$.

${ }^{\star}$ The ratio represents the muscle or adipose tissue mass:carcass weight.

ratios of $1: 1$ and 2:5:1 significantly down-regulated the expression levels of the PPAR $\gamma$ protein in the muscle and adipose tissue $(P<0.05)$, also partially corresponding to the expression levels of the gene.

\section{Discussion}

In the present study, with an accompanying decline in the average daily feed intake and feed conversion rate, the final body weight and daily gain of pigs fed the diet with an $n$-6:n-3 PUFA ratio of 5:1 improved significantly. This result is in agreement with earlier reports showing that a diet with a lower $n-6: n-3$ PUFA ratio, rich in $n-3$ PUFA, is beneficial for the growth performance and health of animals ${ }^{(12-15)}$.

The main components of adipose tissue are fatty acids, which may influence the expression of adipokines, such as adiponectin and leptin ${ }^{(15)}$. Interestingly, the results of the present experiment showed that the serum concentrations of adiponectin of pigs decreased gradually as the dietary $n-6: n-3$ PUFA ratio decreased. Adiponectin is an adipokine exclusively derived from the adipose tissue ${ }^{(16,17)}$. It has been reported that fish oil rich in $n-3$ PUFA increases the serum concentrations of adiponectin in mice 2-3-fold in a dosedependent manner and also in a PPAR $\gamma$-dependent manner ${ }^{(17)}$. However, the present results showed that a low $n-6: n-3$ PUFA ratio could reduce the serum concentrations of adiponectin. The results led us to hypothesise that the serum concentrations of adiponectin are affected by different ratios of dietary $n-6: n-3$ PUFA. Leptin circulates in the body at a concentration highly correlated with white adipose tissue mass and may be of great importance in the regulatory action on body fat ${ }^{(15,18)}$. It has been shown that the serum concentrations of leptin are significantly reduced in mice fed diets with an $n$-6:n-3 PUFA ratio of $1: 1$, but these are not significantly reduced in mice fed diets with $n-6: n-3$ PUFA ratios of $5: 1,10: 1$ and $20: 1^{(19)}$. In the present study, the concentrations of leptin of the group fed the diets with $n-6: n-3$ PUFA ratios of $1: 1$ and $2 \cdot 5: 1$ were higher, indicating that the optimal ratio may vary in different animal models. However, no difference in the serum concentrations of insulin was observed in the present study. We speculated that $n-6: n-3$ PUFA ratios could stimulate the negative feedback regulatory mechanism of adiponectin and leptin.

Immune stimulation in the rearing environment results in the production of potent pro-inflammatory cytokines, which antagonise anabolic growth factors and thus suppress growth. IL-6, IL-1 $\beta$ and TNF- $\alpha$, which are all inflammatory cytokines, initiate the production of an array of inflammatory mediators, thus leading to an inflammatory response. The concentrations of these cytokines are increased on increasing n-6 fatty acid intake and decreased on increasing n-3 fatty acid intake in bovine chondrocytes and in mouse kidney, spleen and peritoneal macrophages, as well as in human monocytes $^{(20)}$. The circulating levels of IL- 6 might reflect, at least in part, the production of IL- 6 in the adipose tissue, although it is also secreted by the exercising muscle ${ }^{(21)}$. The concentrations of IL- 6 decrease by $10 \cdot 5 \%$ on altering the $n-6: n-3$ ratio to $1 \cdot 3^{(22)}$. Moreover, the concentrations of TNF- $\alpha$ decline significantly by $30 \%$ in response to a flaxseed oil diet rich in $n-3$ PUFA and decrease by $74 \%$ after fish oil supplementation ${ }^{(23)}$.

Table 5. Effect of dietary $n-6: n-3$ ratios on serum glucose and cytokine concentrations of pigs

\begin{tabular}{|c|c|c|c|c|c|c|}
\hline \multirow[b]{2}{*}{ Items } & \multicolumn{5}{|c|}{$n-6: n-3$} & \multirow[b]{2}{*}{$P$} \\
\hline & $1: 1$ & $2 \cdot 5: 1$ & $5: 1$ & $10: 1$ & SEM & \\
\hline Glucose $(\mathrm{mmol} / \mathrm{l})$ & 3.56 & 3.13 & 3.62 & 3.63 & 0.24 & 0.44 \\
\hline IL-6 (ng/ml) & $27 \cdot 39^{b}$ & $29.49^{a}$ & $30 \cdot 15^{a}$ & $31 \cdot 23^{a}$ & 0.54 & 0.01 \\
\hline TNF- $\alpha(\mathrm{ng} / \mathrm{ml})$ & 0.23 & 0.22 & 0.24 & 0.26 & 0.01 & 0.30 \\
\hline $\mathrm{IL}-1 \beta(\mathrm{ng} / \mathrm{ml})$ & $0 \cdot 18^{b}$ & $0.26^{a}$ & $0.28^{a}$ & $0.29^{a}$ & 0.02 & 0.02 \\
\hline Adiponectin $(\mu \mathrm{g} / \mathrm{ml})$ & $22 \cdot 07^{\mathrm{b}}$ & $23 \cdot 84^{a, b}$ & $25 \cdot 08^{a}$ & $25.52^{a}$ & 0.69 & 0.03 \\
\hline Leptin (ng/ml) & $2 \cdot 34^{\mathrm{a}}$ & $2 \cdot 12^{\mathrm{a}, \mathrm{b}}$ & $1.96^{\mathrm{b}}$ & $2 \cdot 01^{\mathrm{b}}$ & 0.07 & 0.02 \\
\hline Insulin $(\mu \mathrm{U} / \mathrm{ml})$ & 23.48 & 23.80 & 25.01 & $25 \cdot 13$ & 0.96 & 0.55 \\
\hline
\end{tabular}

${ }^{a, b}$ Values with unlike letters within a row were significantly different $(P<0.05)$. 
(A)

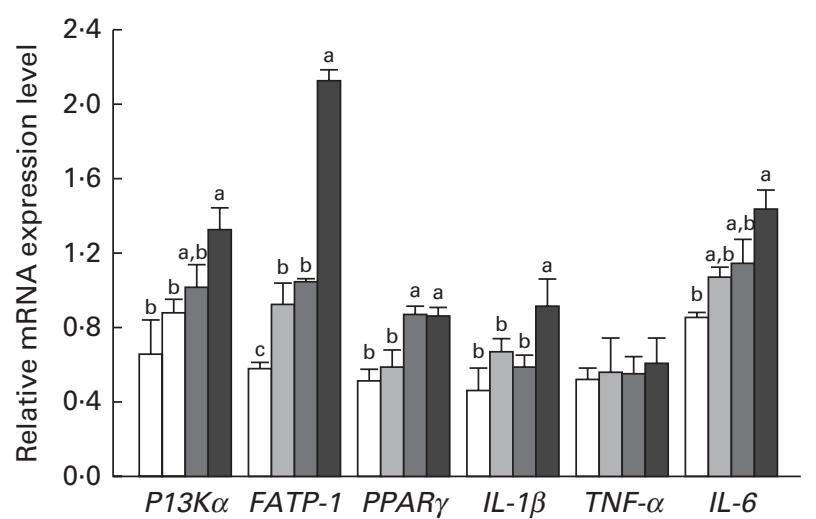

(B)

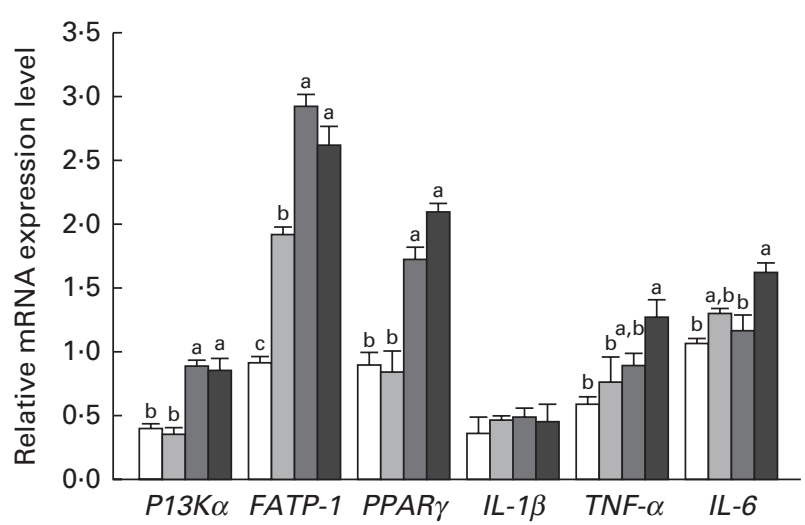

Fig. 1. Relative expression levels of phosphoinositide-3-kinase- $\alpha$ (PIJK $\alpha$ ), fatty acid transport protein-1 (FATP-1), PPAR $\gamma, I L-1 \beta$, TNF- $\alpha$ and IL-6 mRNA in the (A) muscle and (B) adipose tissue of pigs fed diets with $n-6: n-3$ PUFA ratios of 1:1 ( $\square$ ), 2.5:1 ( $\square$ ), 5:1 ( $\square$ ) and 10:1 ( $\square$ ). Real-time PCR method was employed. Values are means $(n 6)$, with their standard errors represented by vertical bars. ${ }^{a, b, c}$ Mean values with unlike letters were significantly different $(P<0.05)$.

The present results also indicated that higher $n$ - 3 PUFA could reduce the serum concentrations of IL- 6 as well as IL- $1 \beta$, but not of TNF- $\alpha$. Additionally, we also found that the expression levels of $I L-6, I L-1 \beta$ and $T N F-\alpha$ mRNA in the skeletal muscle and adipose tissue of pigs fed the diet with an $n-6: n-3$ PUFA ratio 1:1 were markedly down-regulated. Numerous studies have reported that $n-3$ PUFA can decrease the production of these inflammatory cytokines ${ }^{(10,24,25)}$. It has been shown that an optimal $n-6: n-3$ PUFA ratio could regulate several cytokines to reduce inflammatory events in the body.

The PI3K pathway controls essential cellular functions such as signal transduction, cytoskeletal dynamics and membrane trafficking ${ }^{(26)}$. The expression levels of the $P I 3 K \alpha$ gene in mononuclear cells of healthy human subjects have been reported to decrease after supplementation with fish oil ${ }^{(10)}$.
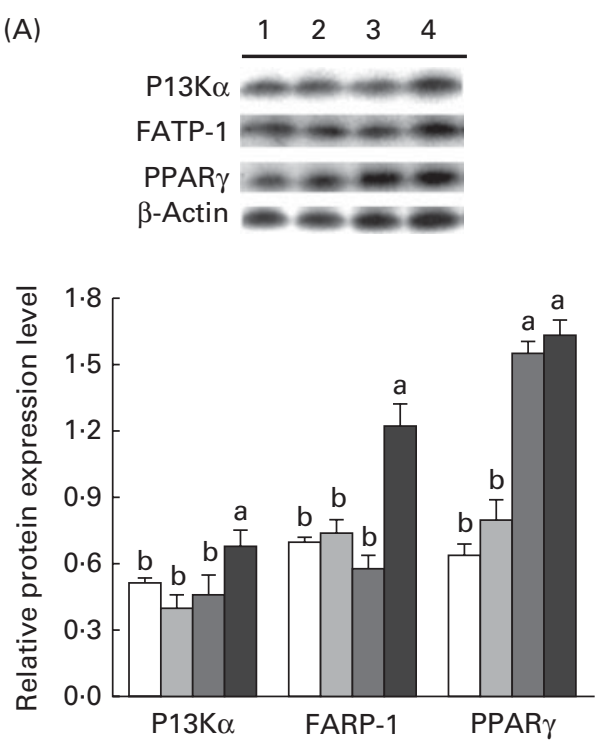

(A)

FARP-1
In the present study, the expression levels of PI3K $\alpha$ gene and protein in the muscle and adipose tissue of pigs fed the diet with an $n-6: n-3$ PUFA ratio of 1:1 were the lowest and the PI3K pathway was activated. In mammals, FATP-1 transports long-chain fatty acids actively across adipocyte cell membranes. In the present study, it was found that the expression levels of FATP-1 mRNA and protein in the muscle and adipose tissue were down-regulated significantly in pigs fed the diet with a lower $n-6: n-3$ PUFA ratio. We speculated that $n-3$ PUFA could suppress adipogenic processes by down-regulating the expression levels of FATP-1 and the optimal dietary ratios of $n-6: n-3$ PUFA might be $1: 1$ and 5:1. PPAR $\gamma$ regulates genes involved in adipocyte differentiation and lipogenesis, while $n$-3 PUFA and their metabolites have been shown to suppress the transcription of lipogenic genes
(B)
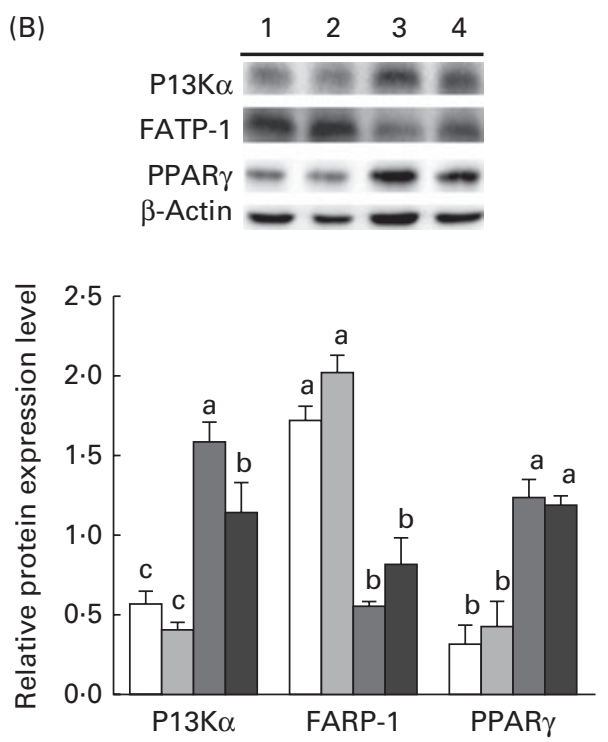

Fig. 2. Relative expression levels of phosphoinositide-3-kinase- $\alpha$ (PI3K $\alpha$ ), fatty acid transport protein-1 (FATP-1) and PPAR $\gamma$ proteins in the (A) muscle and (B) adipose tissue of pigs fed diets with different $n-6: n-3$ PUFA ratios. Western blotting method was employed. Lanes $1,2,3$ and 4 represent $n-6: n-3$ PUFA ratios of 1:1 $(\square)$, 2.5:1 $\square$, $5: 1(\square)$ and 10:1 $(\square)$, respectively. Values are means $(n 6)$, with their standard errors represented by vertical bars. ${ }^{\text {a,b,c }}$ Mean values with unlike letters were significantly different $(P<0 \cdot 05)$. 
by functioning as natural ligands for PPAR ${ }^{(27-31)}$. Interestingly, $n-3$ PUFA and their metabolites can activate the extracellular signal-regulated kinase pathway ${ }^{(29,31,32)}$, which primarily regulates cellular growth and differentiation ${ }^{(33,34)}$. Some previous studies have already demonstrated that PPAR $\gamma$ ligands inhibit the production of IL- 6 , TNF- $\alpha$ and IL-1 $\beta^{(28,35,36)}$ and that TNF- $\alpha$ can inhibit adipocyte differentiation and adipogenesis by suppressing the expression of the PPAR gene ${ }^{(20,36)}$. In the present study, the expression levels of PPAR $\gamma$ gene and protein in both the muscle and adipose tissue of pigs fed the diets with $n-6: n-3$ PUFA ratios of $1: 1$ and $2 \cdot 5: 1$ were markedly reduced. It was observed that a diet with a lower $n$-6:n-3 PUFA ratio could reduce the expression levels of PPAR $\gamma$, which further suppress the transcription of lipogenic genes and lipogenesis.

\section{Conclusion}

On the whole, $n-6: n-3$ PUFA ratios regulate lipid metabolism and inflammation differently and the optimal ratios are 1:1 to $5: 1$, which vary based on the roles under considerations. Optimal n-6:n-3 PUFA ratios could inhibit immune stimulation to ensure the availability of more energy and nutrients for high performance and homeostatic pathways. We speculated that there was a common pathway shared by energy metabolism and inflammation modulation. However, further research is necessary to confirm the results and to illustrate the underlying metabolic pathways.

\section{Acknowledgements}

The present study was jointly supported by the National Basic Research Program of China (2013CB127305, 2012CB124704), the Nanjing Branch Academy of Chinese Academy of Science and Jiangxi Province Cooperation Project, the National Nature Science Foundation of China (31001015, 31110103909) and the Project of Institute of Subtropical Agriculture, the Chinese Academy of Sciences (ISACX-LYQY-QN-1104). None of the funders had any role in the design and analysis of the study and in the writing of this article.

The authors' contributions are as follows: Y. Y., F. L. and L. L. were in charge of the whole trial; Y. D. and F. L. wrote the manuscript; J. F. and X. S. assisted with the animal trial and biochemical analyses.

The authors have no conflicts of interest to declare.

\section{References}

1. Lim GP, Calon F, Morihara T, et al. (2005) A diet enriched with the omega- 3 fatty acid docosahexaenoic acid reduces amyloid burden in an aged Alzheimer mouse model. J Neurosci 25, 3032-3040.

2. Simopoulos AP (2006) Evolutionary aspects of diet, the omega-6/omega-3 ratio and genetic variation: nutritional implications for chronic diseases. Biomed Pharmacother 60, 502-507.

3. Simopoulos AP (2002) The importance of the ratio of omega6/omega-3 essential fatty acids. Biomed Pharmacother $\mathbf{5 6}$ $365-379$.
4. Kobayashi N, Barnard RJ, Henning SM, et al. (2006) Effect of altering dietary $\omega-6 / \omega-3$ fatty acid ratios on prostate cancer membrane composition, cyclooxygenase- 2 , and prostaglandin E2. Clin Cancer Res 12, 4662-4670.

5. Hibbeln JR, Nieminen LR, Blasbalg TL, et al. (2006) Healthy intakes of $n-3$ and $n-6$ fatty acids: estimations considering worldwide diversity. Am J Clin Nutr 83, 1483S-1493S.

6. Gamoh S, Hashimoto M, Hossain S, et al. (2001) Chronic administration of docosahexaenoic acid improves the performance of radial arm maze task in aged rats. Clin Exp Pharmacol Physiol 28, 266-270.

7. Ikemoto A, Ohishi M, Sato Y, et al. (2001) Reversibility of $n-3$ fatty acid deficiency-induced alterations of learning behavior in the rat: level of $n-6$ fatty acids as another critical factor. J Lipid Res 42, 1655-1663.

8. Catalan J, Moriguchi T, Slotnick B, et al. (2002) Cognitive deficits in docosahexaenoic acid-deficient rats. Behav Neurosci 116, 1022-1031.

9. Raheja B, Sadikot SM, Phatak RB, et al. (1993) Significance of the $n-6 / n-3$ ratio for insulin action in diabetes. Ann $N$ Y Acad Sci 683, 258-271.

10. Weaver KL, Ivester P, Seeds M, et al. (2009) Effect of dietary fatty acids on inflammatory gene expression in healthy humans. J Biol Chem 284, 15400-15407.

11. Dutta-Roy AK (2000) Transport mechanisms for long-chain polyunsaturated fatty acids in the human placenta. Am J Clin Nutr 71, Suppl., 315S-322S.

12. Newman RE, Bryden WL, Fleck E, et al. (2002) Dietary n-3 and $n-6$ fatty acids alter avian metabolism: metabolism and abdominal fat deposition. Br J Nutr 88, 11-18.

13. Ferrini G, Baucells MD, Esteve-Garcia E, et al. (2008) Dietary polyunsaturated fat reduces skin fat as well as abdominal fat in broiler chickens. Poult Sci $\mathbf{8 7}, 528-535$.

14. Qi KK (2009) Effect of dietary $\omega 6 / \omega 3$ on fatty acid composition and meat quality in chicken. PhD Thesis, Chinese Academy of Agricultural Sciences, Animal Nutrition Department, Beijing.

15. Drevon CA (2005) Fatty acids and expression of adipokines. Biochim Biophys Acta 1740, 287-292.

16. Stefan N, Wahl HG, Fritsche A, et al. (2001) Effect of the pattern of elevated free fatty acids on insulin sensitivity and insulin secretion in healthy humans. Horm Metab Res 33, 432-438.

17. Neschen S, Morino K, Rossbacher JC, et al. (2006) Fish oil regulates adiponectin secretion by a peroxisome proliferator-activated receptor- $\boldsymbol{\gamma}$-dependent mechanism in mice. Diabetes 55, 924-928.

18. Lago F, Dieguez C, Gómez-Reino J, et al. (2007) The emerging role of adipokines as mediators of inflammation and immune responses. Cytokine Growth Factor Rev 18, 313-325.

19. Xu F, Fan CN, Zhu HY, et al. (2009) Effects of dietary ratio changes of $n-6 / n-3$ polyunsaturated fatty acids on expression of plasma leptin in mice. J Appl Clin Pediatr 24, 500-502.

20. Tai CC \& Ding ST (2010) n-3 Polyunsaturated fatty acids regulate lipid metabolism through several inflammation mediators: mechanisms and implications for obesity prevention. J Nutr Biochem 21, 357-363.

21. Lafontan M \& Langin D (2009) Lipolysis and lipid mobilization in human adipose tissue. Prog Lipid Res $\mathbf{4 8}$, 275-297.

22. Rallidis L, Paschos G, Liakos GK, et al. (2003) Dietary alphalinolenic acid decreases C-reactive protein, serum amyloid A and interleukin-6 in dyslipidaemic patients. Atherosclerosis 167, $237-242$. 
23. Caughey GE, Mantzioris E, Gibson RA, et al. (1996) The effect on human tumor necrosis factor alpha and interleukin 1 beta production of diets enriched in $n-3$ fatty acids from vegetable oil or fish oil. Am J Clin Nutr 63, 116-122.

24. Calder PC (2001) n-3 Polyunsaturated fatty acids, inflammation, and immunity. Lipids 36, 1007-1024.

25. Calder PC (2002) Dietary modification of inflammation with lipids. Proc Nutr Soc 61, 345-358.

26. Lindmo K \& Stenmark H (2005) Regulation of membrane traffic by phosphoinositide 3-kinases. J Cell Sci 119, 605-614.

27. Madsen L, Petersen RK \& Kristiansen K (2005) Regulation of adipocyte differentiation and function by polyunsaturated fatty acids. Biochim Biophys Acta 1740, 266-286.

28. Moraes LA, Piqueras L \& Bishop-Bailey D (2006) Peroxisome proliferator-activated receptors and inflammation. Pharmacol Ther 110, 371-385.

29. Feige JN, Gelman L, Michalik L, et al. (2006) From molecular action to physiological outputs: peroxisome proliferatoractivated receptors are nuclear receptors at the crossroads of key cellular functions. Prog Lipid Res 45, 120-159.
30. Michalik L, Auwerx J, Berger JP, et al. (2006) International union of pharmacology. LXI. Peroxisome proliferatoractivated receptors. Pharmacol Rev 58, 726-741.

31. Edwards IJ \& O'Flaherty JT (2008) Omega-3 fatty acids and PPARg in cancer. PPAR Res 2008, 358052.

32. Camp HS, Tafuri SR \& Leff T (1999) C-Jun N-terminal kinase phosphorylates peroxisome proliferator-activated receptor$\gamma 1$ and negatively regulates its transcriptional activity. Endocrinology 140, 392-397.

33. Dorman CM \& Johnson SE (1999) Activated Raf inhibits avian myogenesis though a MAPK dependent mechanism. Oncogene 18, 5167-5176.

34. Lee MY, Jeong WJ, Oh JW, et al. (2009) NM23H2 inhibits EGF- and Ras-induced proliferation of NIH3T3 cells by blocking the ERK pathway. Cancer Lett 275, 221-226.

35. Jiang C, Ting AT \& Seed B (1998) PPAR-gamma agonists inhibit production of monocyte inflammatory cytokines. Nature 391, 82-86.

36. Escher P \& Wahli W (2000) Peroxisome proliferator-activated receptors: insight into multiple cellular functions. Mutat Res 448, $121-138$ 